九州大学学術情報リポジトリ

Kyushu University Institutional Repository

Identification and Characterization of

Actinomycetes Antagonistic to Pathogenic Vibrio

spp. Isolated from Shrimp Culture Pond

Sediments in Thua Thien Hue-Viet Nam

Chau, Ngo Thi Tuong

Faculty of Biology, Hue College of Sciences, Hue University

Hieu, Nguyen Xuan

Faculty of Biology, Hue College of Sciences, Hue University

Thuan, Le Thi Nam

Faculty of Biology, Hue College of Sciences, Hue University

Matsumoto, Masaru

Institute of Tropical Agriculture, Kyushu University

他

https://doi.org/10.5109/19532

出版情報: 九州大学大学院農学研究院紀要. 56 (1)，pp.15-22，2011-02. Faculty of Agriculture， Kyushu University

バージョン :

権利関係 : 


\title{
Identification and Characterization of Actinomycetes Antagonistic to Pathogenic Vibrio spp. Isolated from Shrimp Culture Pond Sediments in Thua Thien Hue-Viet Nam
}

\author{
Ngo Thi Tuong CHAU ${ }^{1 *}$, Nguyen Xuan HIEU ${ }^{1}$, Le Thi Nam THUAN ${ }^{1}$, \\ Masaru MATSUMOTO and Ikuo MIYAJIMA \\ Institute of Tropical Agriculture, Kyushu University, \\ Fukuoka 812-8581, Japan \\ (Received October 29, 2010 and accepted November 8, 2010)
}

\begin{abstract}
The shrimp diseases in Thua Thien Hue province have mainly accounted for vibriosis caused by Vibrio spp. The addition of substantial amounts of antibiotics is still the method of choice for control the proliferation of pathogenic Vibrio spp. However the abuse of antibiotic agents has led to the emergence of antibiotic-resistant bacteria which may result to resistance transfer to pathogenic bacteria and accumulation of antibiotics in shrimp products. Therefore, developing an alternative strategy to control infections is urgently needed. Following this goal, in the present study, indigenous actinomycetes were isolated from shrimp pond sediments in Thua Thien Hue and strain A1 was screened for their activity against two pathogenic strains Vibrio sp. V7 and V10 derived from diseased shrimps from culture ponds in Thua Thien Hue. Based on the cell morphology observed with a JEOL 5410 LV scanning electron microscope and 16S rRNA nucleotide sequence used to search the GenBank database with the BLAST system, strain A1 was belong to Streptomyces genus and identified as Streptomyces sp. A1. The 16S rRNA sequence of Streptomyces sp. A1 has been deposited in the DDBJ/EMBL/GenBank database with the accession number HM854225. Besides, Streptomyces sp. A1 also showed ability to produce siderophore to acquire iron and extracellular enzymes to decompose organic compounds such as starch, protein and cellulose. Otherwise, Streptomyces sp. A1 was non-pathogenic to shrimp. Therefore, Streptomyces sp. A1 can be considered as not only a candidate for control the shrimp diseases but also a potential probiont for shrimp culture.
\end{abstract}

Keywords: Actinomycetes, probiotic, shrimp pond sediment, vibriosis, Vibrio spp.

\section{INTRODUCTION}

Thua Thien Hue province (Viet Nam) with the largest Tam Giang-Cau Hai coastal lagoon system of Southeast Asia has many favorable conditions for development of shrimp culture. In fact, remarkable increase in shrimp culture helps to restructure the rural economy in a positive direction. However, in recent years, a rapid, largescale and often unplanned increase in brackish water shrimp culture ponds have resulted in shrimp epidemic diseases. The shrimp diseases have mainly accounted for vibriosis caused by Vibrio spp. The addition of substantial amounts of antibiotics is still the method of choice for control the proliferation of pathogenic Vibrio spp. But the abuse of antibiotics has resulted in the development of resistant strains and antibiotic residues in shrimp products. The antibiotic resistance determinants that have emerged and/or evolved in the aquaculture environments have been shown to be transmitted by horizontal gene transfer to bacteria of the terrestrial environment, including animal and human pathogens. The presence of residual antibiotics in commercialized shrimp products constitutes another problem with respect to human health because this can lead to an alteration of the normal human gut microflora and can generate problems of allergy and toxicity (Cabello, 2006). Given the

${ }^{1}$ Faculty of Biology, Hue College of Sciences, Hue University, 77 Nguyen Hue-Hue, Viet Nam

* Corresponding author (E-mail: ngotuongchau@gmail.com) world-wide trade in aquaculture products, health problems related to antibiotic use in aquaculture are not limited to producing countries, but are also relevant to importing countries. Actually, there were many events of returning consignments to Viet Nam from Japan for not maintaining the prescribed standards on residual antibiotics of the products. Therefore, to make the shrimp aquaculture industry more sustainable, alternative strategies to control infections are urgently needed. One of the most successful alternative method has been reported to be the use of probiotics as biological control agents in shrimp aquaculture. As far as you concern, most probiotics proposed as biological control agents in aquaculture are lactic acid bacteria (Lactobacillus, Carnobacterium etc.), Bacillus strains, and Pseudomonas strains (Verschuere et al., 2000). However, most such probiotics in Viet Nam are either imports or domestic products with un-known sources, resulting in a threat of spreading pathogenic and genetically modified strains.

As potential probiotic strains in shrimp culture, actinomycetes have many following advantages: (1) the production of antimicrobial and antiviral agents (Austin, 1989; Oskay et al., 2004); (2) the degradation of complex biological polymers, such as starch and protein (Barcina et al., 1987), lignocellulose, hemicellulose, pectin, keratin, and chitin (Williams et al., 1984) which shows the potential to involve in mineralization and nutrient cycles in the culture ponds and in feed utilization and digestion once getting colonized into the host intestine; (3) the competition for nutrients, particularly iron in 
marine microbes (Kesarcodi et al., 2008); (4) the mostly non-pathogenic to the target animals in aquaculture (Yang et al., 2007); and (5) the formation heat- and desiccation- resistant spores and the retention of viability during preparation and storage. However, reports on probiotics consisting of actinomycetes are meager.

This article gives an account of the actinomycetes strain antagonistic to pathogenic Vibrio spp. isolated from shrimp pond sediments in Thua Thien Hue and also deals with its other probiotic characteristics and sensitivity toward antibiotics. These results may facilitate studies which offer the potential application of actinomycetes for improving the shrimp aquaculture in Thua Thien Hue.

\section{MATERIALS AND METHODS}

\section{Sample Collection and Processing}

Sediment samples were collected from shrimp culture ponds at 3 different sites viz. Lang Co-Phu Loc district $\left(16^{\circ} 13^{\prime} 37^{\prime \prime N}, 108^{\circ} 02^{\prime} 40\right.$ 'E), Thuan An-Phu Vang (16 $31^{\circ} 12$ 'N, 107'38'38”E), and Quang An-Quang Dien district (16 $\left.34^{\prime} 08^{\prime \prime} \mathrm{N}, 107^{\circ} 33^{\prime} 44^{\prime \prime} \mathrm{E}\right)$, Thua Thien Hue, Viet Nam. Collections of the samples were made at 3 different stages of shrimp culture (I, II and III), corresponding to 5, 60 and $105^{\text {th }}$ days of culture during 4 months from January to May 2010 at the sampling sites. Six sediment samples of $5 \mathrm{~g}$ each were collected from $2-5 \mathrm{~cm}$ below the surface of shrimp pond, so that a total of $30 \mathrm{~g}$ represented at each of sample collections. Sediment samples were placed in small pre-labeled sterile plastic bags which were tightly sealed and transported immediately to the laboratory where the sediment samples were dried for one week to obtain the so-called air-dry state then crushed in a mortar and run through a $2-\mathrm{mm}$ mesh sieve and kept in closed plastic bottles for storage at $4^{\circ} \mathrm{C}$.

\section{Sediment properties}

The $\mathrm{pH}\left(\mathrm{H}_{2} \mathrm{O}\right)$ and $\mathrm{pH}(\mathrm{KCl})$ were measured by the glass electrode method using a Hach-C535 (Hach, USA). Total organic carbon (OC), nitrogen (N) and phosphorus $\left(\mathrm{P}_{2} \mathrm{O}_{5}\right)$ were determined by Tiurin's method, Kjeldahl's method and colorimetric method, respectively.

\section{Isolation, identification and characterization of pathogenic Vibrio spp.}

Vibrio spp. were isolated from muscle and liver of moribund diseased tiger shrimps (Penaeus monodon) collected at culture ponds in Thua Thien Hue by spread plate method on Thiosulphate Citrate Bile Sucrose Agar (TCBS, HiMedia), at $35^{\circ} \mathrm{C}$ for $24-48$ hours and kept on Tryptone Soya Agar (TSA, Becton Dickinson) slants containing $1.5 \% \mathrm{NaCl}$.

The pathogenicity of Vibrio spp. to juvenile tiger shrimp (Penaeus monodon) was tested by injecting intramuscularly into healthy shrimps at the site between the third and fourth abdominal segments (Vera et al., 1992) and maintained in plastic basins containing sterile brackish water. Shrimp inoculated with sterile saline served as control. Mortalities were recorded up to $48 \mathrm{~h}$ post-inoculation.

Their phylogenetic characteristics were determined based on the nucleotide sequences of 16S rRNA. DNA extraction of Vibrio spp. was conducted following protocol of Sambrook and Russell (2001). PCR reactions were carried out in a final volume of $25 \mu \mathrm{l}$ containing $0.5 \mu \mathrm{l}$ of template; $2.5 \mu \mathrm{l}$ buffer taq (10X); $3 \mu \mathrm{l} \mathrm{MgCl}_{2}$ (25 mM); $0.625 \mu \mathrm{l}$ of each dNTP $(10 \mathrm{mM}) ; 1.4 \mu \mathrm{l}$ of each primer; and $0.3 \mu \mathrm{l}$ of Taq DNA polymerase $(5 \mathrm{U} / \mu \mathrm{l})$. The bacterial 16S rRNA targeted primer pair consisting of $341 \mathrm{~F}$ and 907R. The amplifications were programmed for an initial denaturation of $5 \mathrm{~min}$ at $95^{\circ} \mathrm{C}$, followed by 35 cycles of $1 \mathrm{~min}$ at $95^{\circ} \mathrm{C}, 55 \mathrm{sec}$ at $58^{\circ} \mathrm{C}$ and $1 \mathrm{~min}$ at $72^{\circ} \mathrm{C}$, and a final extension of $7 \mathrm{~min}$ at $72^{\circ} \mathrm{C}$. The $16 \mathrm{~S}$ rRNA nucleotide sequences were compared with available 16S rRNA nucleotide sequences in GenBank using the BLAST system and submitted to DDBJ/EMBL/GenBank to get respective accession numbers.

The antibiotic susceptibility of Vibrio spp. was performed by disk diffusion method established by Bauer et al. (1966) and standardized by the National Committee for Clinical Laboratory Standards (NCCLS).

\section{Isolation of actinomycetes}

Isolation media consisted of the following (1) the starch casein agar (SCA) (soluble starch $10 \mathrm{~g}$, casein $0.3 \mathrm{~g}, \mathrm{~K}_{2} \mathrm{HPO}_{4} 2 \mathrm{~g}, \mathrm{KNO}_{3} 2 \mathrm{~g}, \mathrm{NaCl} 2 \mathrm{~g}, \mathrm{MgSO}_{4} .7 \mathrm{H}_{2} \mathrm{O} 0.05 \mathrm{~g}$, $\mathrm{CaCO}_{3} 0.02 \mathrm{~g}, \mathrm{FeSO}_{4} \cdot 7 \mathrm{H}_{2} \mathrm{O} 0.01 \mathrm{~g}$, agar $15 \mathrm{~g}$, distilled water to $1 \mathrm{~L}, \mathrm{pH} 7.6)$ added with filtered $(0.2-\mu \mathrm{m}$ pore size) nystatin $(25 \mu \mathrm{g} / \mathrm{l})$ after sterilization at $45-50{ }^{\circ} \mathrm{C}$ to inhibit the growth of fungi and nalidixic acid (10 $\mu \mathrm{g} / \mathrm{l})$ to inhibit the growth of bacteria; (2) the AIM medium (soluble starch $20 \mathrm{~g}, \mathrm{KNO}_{3} 1 \mathrm{~g}, \mathrm{NaCl} 0.5 \mathrm{~g}, \mathrm{~K}_{2} \mathrm{HPO}_{4} 0.5 \mathrm{~g}$, $\mathrm{MgSO}_{4} 0.5 \mathrm{~g}, \mathrm{FeSO}_{4} 20 \mu \mathrm{M}$, agar $15 \mathrm{~g}$, seawater to $1 \mathrm{~L}, \mathrm{pH}$ 7.6) supplemented with nystatin $(25 \mu \mathrm{g} / \mathrm{l})$ and nalidixic $(15 \mu \mathrm{g} / \mathrm{l})$. One gram samples of dried sediments were diluted $\left(10^{-2}\right.$ to $\left.10^{-5}\right)$ in sterile saline solution $(0.85 \% \mathrm{w} / \mathrm{v}$ $\mathrm{NaCl}) .100 \mu \mathrm{l}$ of each dilution was plated onto isolation media in triplicate petri dishes. The inoculated plates were incubated at $35^{\circ} \mathrm{C}$ for 7 days. After incubation, actinomycetes isolates distinguished from other microbial colonies by characteristics such as tough, leathery colonies which are partially submerged into the agar were purified by streak plate method and maintained on SCA slant at $4^{\circ} \mathrm{C}$.

\section{Activities against Vibrio spp. of actinomycetes iso- lates}

The activities against pathogenic Vibrio strains of actinomycetes isolates were determined using the double-layer agar method. The actinomycetes were inoculated on petri dishes containing $15 \mathrm{ml}$ SCA and incubated at $35^{\circ} \mathrm{C}$ for 3 days. Then TCBS agar medium (HiMedia) was poured onto the basal layer containing actinomycete colonies. Vibrio strains were inoculated in flask containing $50 \mathrm{ml}$ peptone alkaline (10 g peptone, $\mathrm{NaCl} 10 \mathrm{~g}$, distilled water to $1 \mathrm{~L}, \mathrm{pH} 8.5$ ) at $30{ }^{\circ} \mathrm{C}$ for 24 hours. Then Vibrio spp. was plated onto the top layer, respectively. The inhibition zones were measured after incubation at 
$35{ }^{\circ} \mathrm{C}$ for 24 hours (You et al., 2005). The actinomycetes strains with high activities against pathogenic Vibrio spp. were screened for further studies.

\section{Identification of actinomyces}

\section{Electron microscopy}

Cultures grown SCA medium were harvested, and fixed with $2.5 \%$ (w/v) glutaraldehyde in $0.1 \mathrm{M}$ sodium phosphate buffer ( $\mathrm{pH}$ 7.2) for $30 \mathrm{~min}$ and transferred to a gold mesh for $1 \mathrm{~min}$ to fix on it. The samples were rinsed lightly with deionized water and then dehydrated sample with a series of ethanol concentrations (25, 50, 75 and 100\%). The resulting preparations were transferred to T-butyl, dried with a lyophilizer, coated with gold, and observed with a JEOL 5410 LV scanning electron microscope. The morphology of actinomycetes was photographed.

Nucleic acid extraction, $16 S$ rRNA amplification, sequencing and analysis

Colonies were transferred into $1.5 \mathrm{ml}$ eppendorf tubes containing $200 \mu \mathrm{l} 10 \mathrm{mM} \mathrm{TE}(\mathrm{pH} 8.0)$ and vortex thoroughly. The suspensions were added with $200 \mu \mathrm{l} 20 \%$ SDS, vortex gently, incubated at $65^{\circ} \mathrm{C}$ for $4 \mathrm{~min}$, and centrifuged at $10,000 \mathrm{rpm}$ for $10 \mathrm{~min}$ at $4^{\circ} \mathrm{C}$. The supernatants and pellets were transferred into new eppendorf tubes separately. Eppendorf tubes containing cell pellets were placed into the microwave oven set at low level, for $30 \mathrm{sec}$ with 3 times of repeats. These cell pellets were mixed well the supernatants. The suspensions were added with $500 \mu \mathrm{l}$ chloroform/isoamyl alcohol (24:1), turned upside down and centrifuged at 12,000 rpm for $10 \mathrm{~min}$ at $4{ }^{\circ} \mathrm{C}$. The aqueous (upper) phases were carefully transferred to new eppendorf tubes, precipitated with $400 \mu \mathrm{l}$ isopropanol (1:1) supplemented with $10 \%$ sodium acetate, kept at $-20{ }^{\circ} \mathrm{C}$ for $2-3$ hours and centrifuged at $12,000 \mathrm{rpm}$ for $10 \mathrm{~min}$ at $4^{\circ} \mathrm{C}$. The supernatants were discarded. The pellets were added with $1 \mathrm{ml} 70 \%$ ethanol, centrifuged at $12,000 \mathrm{rpm}$ for $10 \mathrm{~min}$ at $4{ }^{\circ} \mathrm{C}$ and dried in a speed vacuum concentrator. The pellets were dissolved in $20 \mu \mathrm{l}$ sterile deionnized water. The DNA obtained is further referred to as crude DNA. The $16 \mathrm{~S}$ rRNA sequencing temple was amplified by PCR using primers $341 \mathrm{~F}$ and 907R. Reaction mixture (25 $\mu \mathrm{l})$ contained $0.5 \mu \mathrm{l}$ of template; $2.5 \mu \mathrm{l}$ buffer taq (10X); $3 \mu \mathrm{l}$ $\mathrm{MgCl}_{2}(25 \mathrm{mM}) ; 0.625 \mu \mathrm{l}$ of each dNTP $(10 \mathrm{mM}) ; 1.4 \mu \mathrm{l}$ of each primer; and $0.3 \mu \mathrm{l}$ of Taq DNA polymerase (5U/ $\mu \mathrm{l})$. All sequencing reactions were carried out with an ABI PRISM 3100 genetic analyzer programmed for an initial denaturation of $5 \mathrm{~min}$ at $95^{\circ} \mathrm{C}$, followed by 35 cycles of $1 \mathrm{~min}$ at $95^{\circ} \mathrm{C}, 55 \mathrm{sec}$ at $58^{\circ} \mathrm{C}$ and $1 \mathrm{~min}$ at $72^{\circ} \mathrm{C}$, and a final extension of $7 \mathrm{~min}$ at $72^{\circ} \mathrm{C}$. The $16 \mathrm{~S}$ rRNA sequences (540 bp) were used to search the GenBank database with the BLAST system to reveal closest matches to the 16S rRNA nucleotide sequences for known species and submitted to DDBJ/EMBL/GenBank to get respective accession number.

\section{Production of extracellular enzymes}

Ability to produce extracellular enzymes such as amylase, protease and cellulase of actinomycetes were tested on SCA plates containing separately $1 \%$ starch, $1 \%$ CMC (carboxymethyl cellulose), and $1 \%$ casein, at $35{ }^{\circ} \mathrm{C}$ for 3 days. Lugol's reagent was used to find the degradation of starch and CMC, whereas Fraziaer's reagent was used to find the degradation of casein.

\section{Siderophore production}

Production of siderophores by the actinomycetes isolate was determined using CAS assay solutions in cellfree culture supernatants (Payne, 1994). For the detection of siderophores by the CAS assay method, the isolate was grown in iron deficient defined medium MM9, $100 \mathrm{mM}$ Pipes buffer, 0.2\% glucose, 0.095\% $\mathrm{MgCl}_{2}, 0.011 \%$ $\mathrm{CaCl}_{2}$ at $30^{\circ} \mathrm{C}$ for 72 hours. Cell free culture supernatants were obtained by centrifugation of the cultures at $6,000 \mathrm{rpm}, 4^{\circ} \mathrm{C}$ for $15 \mathrm{~min}$, followed by filtration using $0.2 \mu \mathrm{m}$ pore size filters. One milliliter of cell-free culture supernatant thus prepared and $1 \mathrm{ml}$ of CAS assay solution were mixed, then added $20 \mu \mathrm{l}$ shuttle solution $(0.2 \mathrm{M}$ 5-sulfosalicylic acid) and after equilibrium was reached, absorbance of this solution at $630 \mathrm{~nm}$ was recorded using spectrophotometer. The minimal medium was served as a blank and the minimal medium plus CAS assay solution plus shuttle were served as a reference $(r)$. The sample (s) should have a lower reading than the reference. Siderophore units are defined as $\left[\left(A_{r}-A_{s}\right) / A_{r}\right] 100=\%$ siderophore units.

\section{Pathogenicity of actinomycetes to $P$. monodon lar- vae}

The larvae of $P$. monodon (stage PL 9) were maintained for 4 days in brackish water (20 ppt) and fed with commercial feed. 50 PL were distributed in 20-L plastic plastic basins containing $10 \mathrm{~L}$ of sterile brackish water. The actinomycetes was cultured in SCA at $35^{\circ} \mathrm{C}$ for 3 days and were scraped from the surface of the plates using a sterile loop and suspended in sterile saline solution to saline solution to McFarland 0.5 standard, corresponding to approximate $10^{8}$ cfu per milliliter. The shrimp larvae were challenged at $10^{5}$ cfu per milliliter. The experiment was carried out in triplicate. The larval mortality was monitored for up to 4 days.

\section{Antibiotic susceptibility of actinomycetes}

The antibiotic susceptibility was performed by disk diffusion method established by Bauer et al. (1966) and standardized by National Committee for Clinical Laboratory Standards (NCCLS). A total of 7 antibiotic discs (bioMérieux, France) which includes ampicillin (10 $\mu \mathrm{g})$, erythromycin (15 $\mu \mathrm{g})$, chloramphenicol (30 $\mu \mathrm{g})$, ciprofloxacin $(5 \mu \mathrm{g})$, tetracycline $(30 \mu \mathrm{g})$, gentamicin $(10 \mu \mathrm{g})$, penicillin-G $(10 \mu \mathrm{g})$ were employed. The actinomycetes suspension with the same density as the McFarland 0.5, was streaked with a sterile swab over the entire surface of Muller- Hinton agar plates and the antimicrobial discs were soon applied to the plates. The plates were incubated at $35^{\circ} \mathrm{C}$ for 24 hours. Inhibitory zone size was measured in millimeter and compared with the standard interpretative chart of Vibrio cholerae (except ciprofloxacin, erythromycin and penicillin-G of 
Enterobacteriaceae, Enterococcus and staphylococci, respectively) to determine their antibiotic sensitivity.

\section{RESULTS}

\section{Sediment properties}

Sediment samples were collected from three different locations and their properties were determined (Table 1). $\mathrm{pH}\left(\mathrm{H}_{2} \mathrm{O}\right)$ averaged 7.6 in a range of 7.1 and 8.0. It is likely to suitable because shrimp pond bottom soils always need to have a pH of 7.5 or above to encourage decomposition of organic matter. The high $\mathrm{pH}$ reflects the effect of the applications of liming materials into dry shrimp pond bottom.

The highest contents of organic carbon (OC), nitrogen $(\mathrm{N})$ and $\mathrm{P}_{2} \mathrm{O}_{5}$ were found in the Lang $\mathrm{Co}-\mathrm{Phu}$ Loc (I), Thuan An-Phu Vang (II) and Quang An-Quang Dien (III) sediments, respectively. The Quang An-Quang Dien sample was likely to be the one with highest content of the organic matter. The content of organic carbon averaged $1.07 \%$ with a range of $0.68-2.06 \%$. These findings also agree with the observation that aquaculture ponds situated on mineral soil seldom contain more than 3\% organic carbon (Boyd, 1995). A factor of 1.9 times organic carbon concentration is thought to provide a reasonable estimate of organic matter in surface soil (Nelson and Sommers, 1982). Nitrogen averaged 0.19\% with a range of $0.11-0.39 \%$ and $\mathrm{P}_{2} \mathrm{O}_{5}$ averaged $0.55 \%$ with a range of $0.03-0.09 \%$.

\section{Isolation, identification and characterization of pathogenic Vibrio spp.}

Based on typical colonial morphology of Vibrio spp. on TCBS agar after incubating at $35^{\circ} \mathrm{C}$, for $24-48$ hours, 15 strains were isolated from diseased shrimp samples (Fig. 1) and coded from V1 to V15. Then they were selected for the pathogenicity to juvenile tiger shrimp (Penaeus monodon). The severity of pathogenicity depends on strain of Vibrio involved. Strains V7 and V10 were found to cause $100 \%$ mortality of shrimp at the infection levels of $10^{6}$ and $10^{7} \mathrm{cfu} / \mathrm{g}$, respectively. No mortality was observed for shrimps in the control group and remains. Therefore, strains V7 and V10 were used for further studies.

The 16S rRNA nucleotide sequence of strain V7 (Fig. 2) reached a 98.5\% indentity with $16 \mathrm{~S}$ rRNA nucleotide sequence of Vibrio harveyi ACMM $642 ; V$. campbellii ATCC $25920^{\mathrm{T}}$; $V$. parahaemolyticus RIMD 2210633; V. rotiferianus $\mathrm{R}-14939^{\mathrm{T}}$; $V$. owensii 47666-1. Meanwhile, the 16S rRNA nucleotide sequence of strain V10 (Fig. 3) showed an identity of $99.6 \%$ with Vibrio parahaemolyticus ATCC 17802; V. parahaemolyticus JGX080708; V. alginolyticus GCSL 29; Vibrio sp. V170; and of $98.5 \%$ with $V$. harveyi SW-4; Vibrio sp. LC1-257. The strains V7 and V10 could be identified as Vibrio sp. V7 and Vibrio sp. V10, respectively. The 16S rRNA nucleotide sequences of strains V7 and V10 determined in this study have been deposited in the DDBJ/EMBL/ GenBank database with the accession numbers HM854227

Table 1. Properties of sediments from shrimp ponds in Thua Thien Hue province

\begin{tabular}{lcccccc}
\hline \multicolumn{1}{c}{ Sample } & Stage & $\mathbf{p H}\left(\mathbf{H}_{\mathbf{2}} \mathbf{O}\right)$ & $\mathbf{p H}(\mathbf{K C l})$ & $\mathbf{O C}(\%)$ & $\mathbf{N}(\%)$ & $\mathbf{P}_{\mathbf{2}} \mathbf{O}_{\mathbf{5}}(\mathbf{\%})$ \\
\hline \multirow{2}{*}{ Lang Co-Phu Loc } & I & 8.0 & 6.5 & 2.06 & 0.15 & 0.08 \\
& II & 7.9 & 7.7 & 0.74 & 0.15 & 0.07 \\
Thuan An-Phu Vang & II & 7.7 & 7.6 & 0.68 & 0.16 & 0.05 \\
& I & 7.9 & 7.6 & 0.86 & 0.18 & 0.04 \\
& II & 7.1 & 6.7 & 0.86 & 0.11 & 0.03 \\
Quang An-Quang Dien & III & 7.4 & 7.0 & 0.80 & 0.18 & 0.03 \\
& I & 7.9 & 7.6 & 1.22 & 0.24 & 0.08 \\
& II & 7.2 & 6.6 & 1.13 & 0.39 & 0.08 \\
\hline
\end{tabular}

Stage I; $5^{\text {th }}$ day, Stage II; $60^{\text {th }}$ day, Stage III; $105^{\text {th }}$ day of shrimp culture, OC; organic carbon

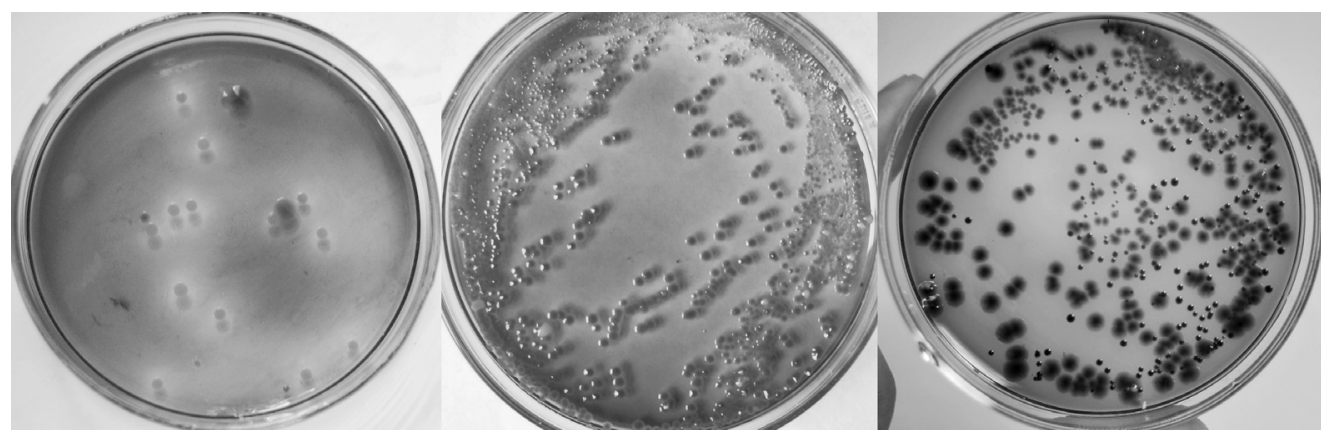

Fig. 1. Colonial morphology of Vibrio spp. isolated from (a) Lang Co- Phu Loc, (b) Quang An- Quang Dien, (c) Loc Dien- Phu Loc on TCBS at $35^{\circ} \mathrm{C}, 24-48 \mathrm{~h}$. 
Table 2. Zone diameter interpretive standards and antibiotic susceptibility of Vibrio sp. V7 and Vibrio sp. V10

\begin{tabular}{|c|c|c|c|c|c|c|c|c|c|}
\hline \multirow{3}{*}{$\begin{array}{l}\begin{array}{c}\text { Antimicrobial agent } \\
\text { (Disk Content ) }\end{array} \\
\text { Ampicillin }(10 \mu \mathrm{g})\end{array}$} & \multicolumn{3}{|c|}{ Diameter of zone of inhibition (mm) } & \multirow{3}{*}{$\begin{array}{c}\boldsymbol{E} . \text { coli } \\
\text { ATCC } 25922 \\
23\end{array}$} & \multirow{3}{*}{$\begin{array}{c}\text { S. aureus } \\
\text { ATCC } 25923 \\
35\end{array}$} & \multirow{2}{*}{\multicolumn{2}{|c|}{$\begin{array}{c}\text { Vibrio sp. } \\
\quad \text { V7 }\end{array}$}} & \multirow{2}{*}{\multicolumn{2}{|c|}{$\begin{array}{c}\text { Vibrio sp. } \\
\text { V10 }\end{array}$}} \\
\hline & \multirow{2}{*}{$\begin{array}{c}\text { Resistant } \\
\text { (R) } \\
\leq 13\end{array}$} & \multirow{2}{*}{$\begin{array}{c}\text { Intermediate } \\
\text { (I) } \\
14-16\end{array}$} & \multirow{2}{*}{$\begin{array}{l}\text { Susceptible } \\
\text { (S) } \\
\quad \geq 17\end{array}$} & & & & & & \\
\hline & & & & & & 15 & I & 7 & $\mathrm{R}$ \\
\hline Erythromycin $(15 \mu \mathrm{g})$ & $\leq 13$ & $14-22$ & $\geq 23$ & 10 & 30 & 21 & I & 20 & I \\
\hline Chloramphenicol (30 $\mu \mathrm{g})$ & $\leq 12$ & $13-17$ & $\geq 18$ & 26 & 26 & 34 & $\mathrm{~S}$ & 35 & $\mathrm{~S}$ \\
\hline Ciprofloxacin $(5 \mu \mathrm{g})$ & $\leq 15$ & $16-20$ & $\geq 21$ & 40 & 28 & 35 & $\mathrm{~S}$ & 30 & S \\
\hline Tetracycline $(30 \mu \mathrm{g})$ & $\leq 14$ & $15-18$ & $\geq 19$ & 25 & 28 & 27 & $\mathrm{~S}$ & 29 & $\mathrm{~S}$ \\
\hline Gentamicin $(10 \mu \mathrm{g})$ & $\leq 12$ & $13-14$ & $\geq 15$ & 20 & 22 & 14 & I & 19 & $\mathrm{~S}$ \\
\hline Penicillin- G $(10 \mu \mathrm{g})$ & $\leq 28$ & not suitable & $\geq 29$ & 7 & 37 & 7 & $\mathrm{R}$ & 7 & $\mathrm{R}$ \\
\hline
\end{tabular}

1 CTTCGGGTTG TAAAGCACTT TCAGTCGTGA GGAAGGTAGT GTAGTTAATA GCTGCATTAT 61 TTGACGTTAG CGACAGAAGA AGCACCGGCT AACTCCGTGC CAGCAGCCGC GGTAATACGG 121 AGGGTGCGAG CGTTAATCG AATTACTGGG CGTAAAGCGC ATGCAGGTGG TTTGTTAAGT 181 CAGATGTGAA AGCCCGGGGC TCAACCTCG AATTGCATTT GAAACTGGCG AGACTAGAGT 241 ACT GT AGAGG GGGGTAGAAT TTCAGGTGTA GCGGTGAAAT GCGTAGAGAT CTGAAGGAAT 301 ACCGGTGGCG AAGGCGGCCC CCTGGACAGA TACTGACACT CAGATGCGAA AGCGTGGGGA 361 GCAAACAGGA TTAGATACCC TGGTAGTCCA CGCCGTAAAC GATGTCTACT TGGAGGTTGT 421 GGCCTTGAGC CGTGGCTTTC GGAGCTAACG CGTTAAGTAG ACCGCCTGGG GAGTACGGTC 481 GCAAGATTAA A

Fig. 2. The $16 \mathrm{~S}$ rRNA nucleotide sequence of strain V7.
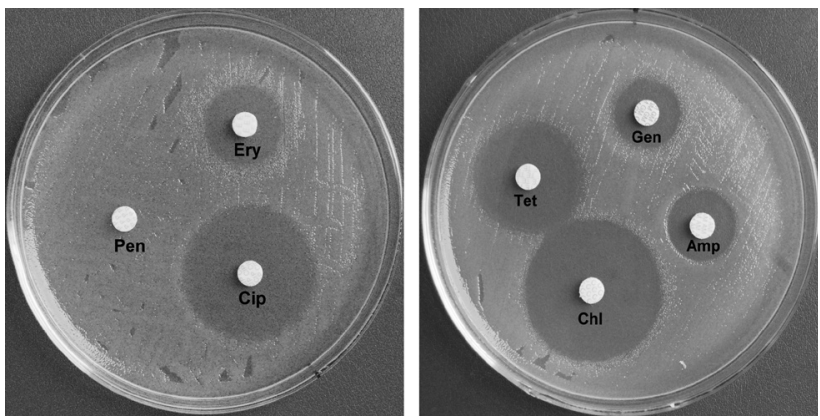

Fig. 4. Antibiotics sensitivities of Vibrio sp. V7.

and HM854228, respectively.

Antibiotics sensitivities tests revealed Vibrio sp. V7 and Vibrio sp. V10 to be sensitive to chloramphenicol (Chl), ciprofloxacin (Cip), tetracycline (Tet), intermediate to erythromycin (Ery), and resistant to penicillin-G (Pen). However, Vibrio sp. V10 was resistant to ampicillin (Amp) and sensitive to gentamicin (Gen), while Vibrio sp. V7 was intermediate to ampicillin (Amp) and gentamicin (Gen) (Table 2, Fig. 4, 5).

\section{Isolation of actinomycetes}

A total of 50 strains of actinomycetes was isolated using three different agar media from the sediment samples collected at different locations. Strain A1 showed good growth on SCA after 3 days (Fig. 6).

\section{Activities against Vibrio spp. of actinomycetes iso- lates}

All actinomycetes isolates were screened for their activities against two strains Vibrio sp. V7 and V10 using
1 GGGCGCAAGC CTGATGCAGC CATGCCGCGT GTGTGAAGAA GGCCTTCGGG TTGTAAAGCA 61 CTTTCAGTCG TGAGGAAGGT GGTAGTGTTA ATAGCACTAT CATTTGACGT TAGCGACAGA 121 AGAAGCACCG GCTAACTCCG TGCCAGCAGC CGCGGTAATA CGGAGGGTGC GAGCGTTAAT 181 CGGAATTACT GGGCGTAAAG CGCATGCAGG TGGTTTGTTA AGTCAGATGT GAAAGCCCGG 241 GGCTCAACCT CGGAATTGCA TTTGAAACTG GCAGACTAGA GTACTGTAGA GGGGGTAGA 301 ATTTCAGGTG TAGCGGTGAA ATGCGTAGAG ATCTGAAGGA ATACCGGTGG CGAAGGCGGC 361 CCCCTGGACA GATACT GACA CTCAGATGCG AAAGCGTGGG GAGCAAACAG GATTAGATAC 421 CCTGGTAGTC CACGCCGTAA ACGATGTCTA CTTGGAGGTT GTGGCCTTGA GCCGTGGCTT 481 TCGGAGCTAA CGCGTTAAGT AGACCGCCTG GGGAGTACGG TCGCAAGATT AAAACTCAAA 541 TGAATTGACG GGAA

Fig. 3. The $16 \mathrm{~S}$ rRNA nucleotide sequence of strain V10.
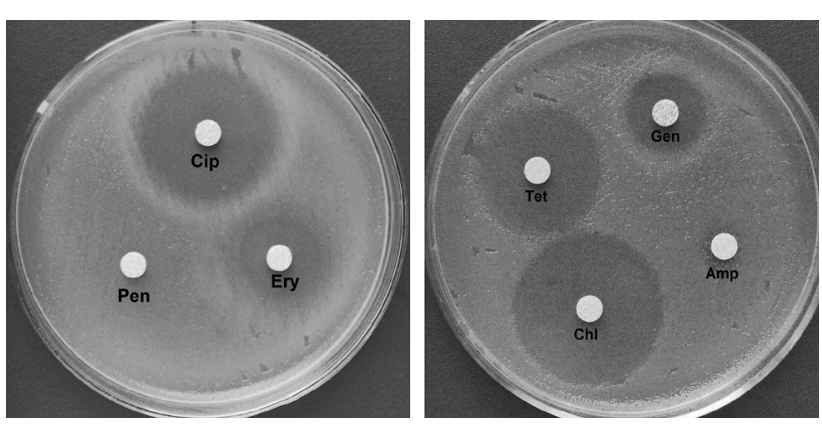

Fig. 5. Antibiotics sensitivities of Vibrio sp. V10.
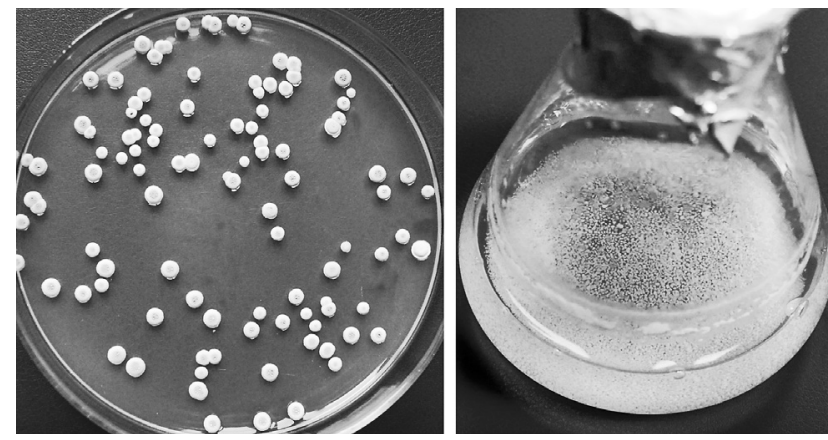

Fig. 6. Colonial morphology and biomass of strain A1 isolated from Quang An-Quang Dien sediment on SCA medium.

the double-layer agar method. Of these, strain A1 showed the highest activity against both strains V7 and V10 (Fig. 7). The diameters of zone antagonistic to strains V7 and V10 were 40 and $36 \mathrm{~mm}$, respectively. Therefore, strain A1 was selected for further studies. 

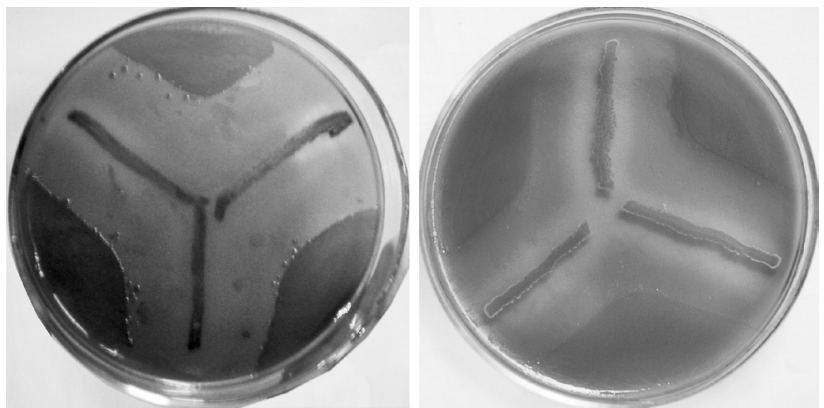

Fig. 7. Activities against Vibrio sp. V7 (left) and V10 (right) of strain A1.

\section{Identification of strain A1}

A photograph of strain A1 taken using a JEOL 5410 LV scanning electron microscope was shown in Fig.8. The 16S rRNA nucleotide sequence of strain A1 was determined and presented in Fig. 9. The result of the homology search with GeneBank database using the BLAST system indicated that the 16S rRNA nucleotide sequence of strain A1 had a 95.5\% identity with that of Streptomyces sp. An53; S. griseoaurantiacus DSM 40430; Streptomyces sp. ME02-6978.2a; S. griseoaurantiacus NBRC $15440^{\mathrm{T}}$. Therefore, strain A1 was considered to belong genus Streptomyces and identified as Streptomyces sp. A1. The 16S rRNA nucleotide sequence of Streptomyces sp. A1 has been deposited in the DDBJ/ EMBL/GenBank database with the accession number HM854225.

\section{Production of extracellular enzymes}

Ability to produce extracellular enzymes to decompose organic compounds, such as starch, protein and cellulose, by strain A1 also was presented in Fig. 10. It may
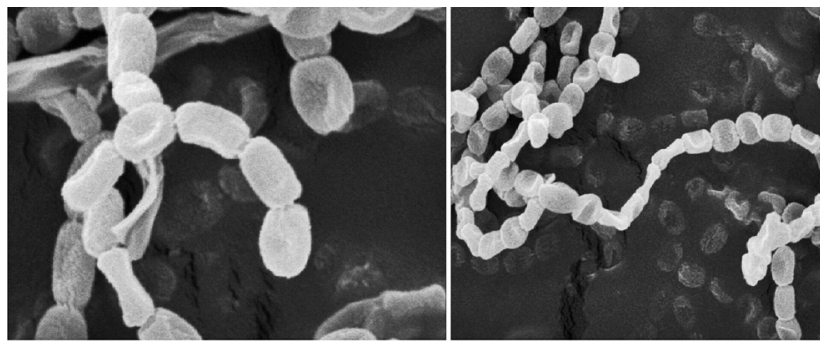

Fig. 8. Microscopic characteristic of Streptomyces sp. A1 be due to actinomycetes are primarily saprophytic soildwelling organisms (Williams et al., 1984). This help to degrade the unconsumed feed and feces in the culture pond, in addition to the possible role of these enzymes in the nutrition of the shrimps by improving feed digestibility and feed utilization. Once actinomycetes get colonized into the host intestine, the exoenzymes produced by actinomycetes may be helpful in facilitating feed utilization and digestion (Das et al., 2008).

\section{Siderophore production}

Streptomyces sp. A1 was found to produce $40 \%$ siderophore units as detected by the CAS assay technique. Therefore, Streptomyces sp. A1 could not only inhibit the growth of all Vibrio spp., but also produce siderophores.

\section{Pathogenicity of Streptomyces sp. A1 to P. mono- don larvae}

The pathogenicity of Streptomyces sp. A1 test on larvae of $P$. monodon indicated that the strain A1 did not cause any significant mortality after 4 days of challenge $\left(10^{5}\right.$ cfu per milliliter). This result agree with the virulence factor database (Yang et al., 2007) (accessed on 14 September 2008) suggested that Streptomyces will not cause harm to the target animals in aquaculture.

\section{Antibiotic susceptibility of Streptomyces sp. A1}

Antibiotics sensitivities tests revealed Streptomyces sp. A1 to be sensitive to chloramphenicol (Chl), ciprofloxacin (Cip) and gentamicin (Gen), to intermediate to erythromycin (Ery), and resistant to ampicillin (Amp), tetracycline (Tet) and penicillin-G (Pen) (Table 3, Fig. $11)$.

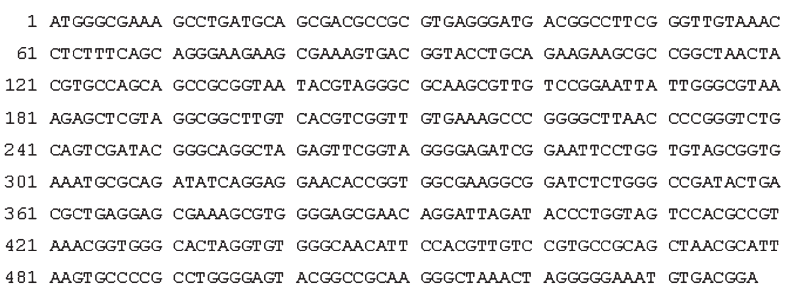

Fig. 9. The 16S rRNA nucleotide sequence of strain Streptomyces sp. A1.
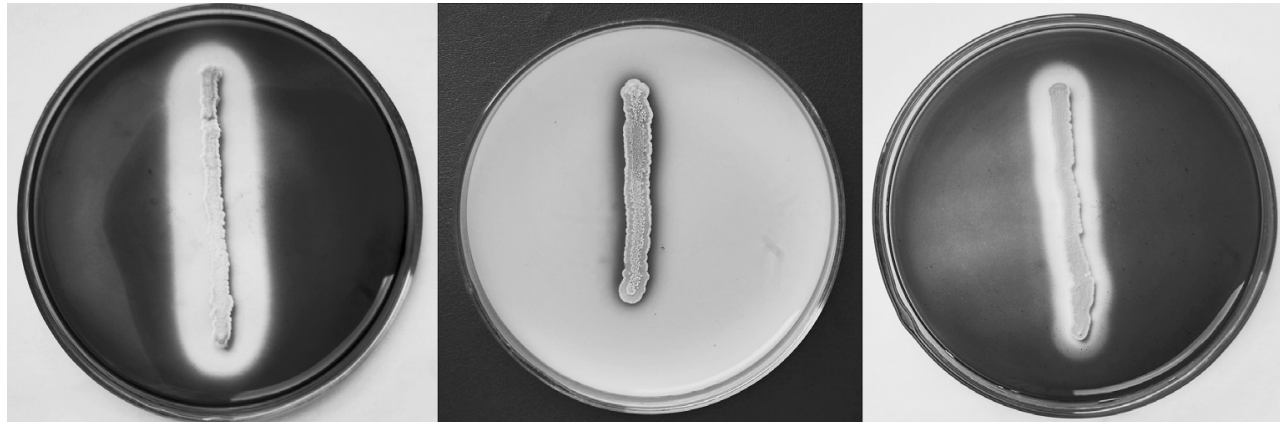

Fig. 10. Degradation of starch (left), casein (middle), cellulose (right) of Streptomyces sp. A1 
Table 3. Zone diameter interpretive standards and antibiotic susceptibility of Streptomyces sp. A1

\begin{tabular}{|c|c|c|c|c|c|c|c|}
\hline $\begin{array}{l}\text { Antimicrobial agent } \\
\text { (Disk Content ) }\end{array}$ & \multicolumn{3}{|c|}{ Diameter of zone of inhibition (mm) } & $\begin{array}{c}E . \text { coli } \\
\text { ATCC } 25922\end{array}$ & $\begin{array}{c}\text { S. aureus } \\
\text { ATCC } 25923\end{array}$ & \multicolumn{2}{|c|}{$\begin{array}{c}\text { Streptomyces sp. } \\
\text { A1 }\end{array}$} \\
\hline Ampicillin (10 $\mu \mathrm{g})$ & $\leq 13$ & $14-16$ & $\geq 17$ & 23 & 35 & 0 & $\mathrm{R}$ \\
\hline Erythromycin $(15 \mu \mathrm{g})$ & $\leq 13$ & $14-22$ & $\geq 23$ & 10 & 30 & 20.5 & I \\
\hline Ciprofloxacin $(5 \mu \mathrm{g})$ & $\leq 15$ & $16-20$ & $\geq 21$ & 40 & 28 & 29.0 & S \\
\hline Tetracycline $(30 \mu \mathrm{g})$ & $\leq 14$ & $15-18$ & $\geq 19$ & 25 & 28 & 13.0 & $\mathrm{R}$ \\
\hline Gentamicin $(10 \mu \mathrm{g})$ & $\leq 12$ & $13-14$ & $\geq 15$ & 20 & 22 & 34.5 & S \\
\hline Penicillin- G $(10 \mu \mathrm{g})$ & $\leq 28$ & not suitable & $\geq 29$ & 7 & 37 & 0 & $\mathrm{R}$ \\
\hline
\end{tabular}
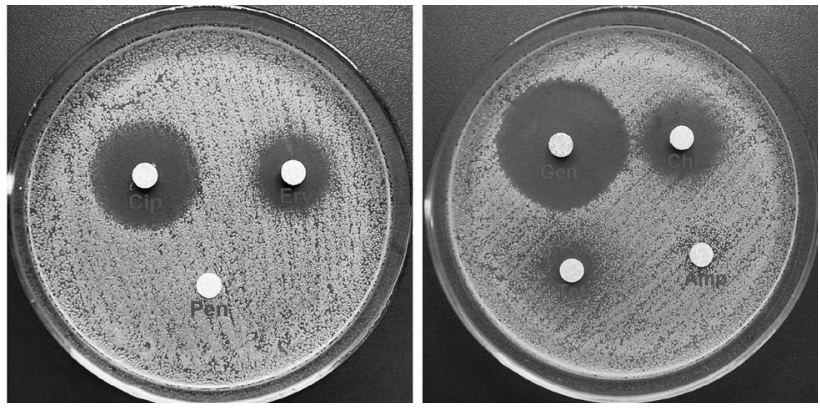

Fig. 11. Antibiotics sensitivities of Streptomyces sp. A1.

\section{DISCUSSION}

Many factors affect the concentration of organic matter in pond soils. Soil matter used in pond construction may vary in organic matter concentration among sites, and methods of pond management will affect rates of both input and decomposition of organic matter in pond soils. Within a given pond, there is usually an increase in soil organic matter in the surface $5 \mathrm{~cm}$ layer during a growing season (Gately, 1990). As far as you concern, organic matter with a $\mathrm{C} / \mathrm{N}$ ratio of 10 to 15 will decompose much faster than organic matter with higher $\mathrm{C} / \mathrm{N}$ ratios (Boyd, 1992). In this study, lower $\mathrm{C} / \mathrm{N}$ ratio suggested the presence of more easily degradable organic matter in the shrimp pond sediments of Thua Thien Hue, particularly in the sediment of Quang An-Quang Dien. It is suitable that Streptomyces sp. A1 antagonistic to pathogenic strains Vibrio sp. V7 and V10 was derived from the sediment of Quang An-Quang Dien. The mortality (100\%) of shrimps intramuscularly injected with Vibrio sp. V7 and V10 was observed after only 8 and 5 hours of injection, respectively. This phenomenon should be study further. Besides, Vibrio sp. V7 was resistant to penicillin-G and Vibrio sp. V10 was resistant to penicillin-G and ampicillin. This result was similar to that of Najiah et al. (2008) reported that $90 \%$ of $V$. harveyi isolates were mostly resistant to ampicillin. Besides, the resistance to ampicillin in $V$. harveyi isolated from aquaculture facilities in Asia and South America was reported (Teo et al., 2002; Molina-Aja et al., 2002; Nakayama et al., 2006). Also, V. parahaemolyticus isolated from red disease affected shrimp was resistant to ampicillin and penicillin-G (Jayasree et al., 2006). The development of resistance was accounted for use of antibiotics in shrimp culture systems. The alternative measures that have recently been developed to control disease caused by $V$. harveyi and closely related bacteria include phage therapy, the use of short-chain fatty acids and polyhydroxyalkanoates, quorum-sensing disruption, probiotics and green water. Of them, the application of probiotics have a longer history (Tom et al., 2007). Possible modes of action for probiotics include (i) production of inhibitory compounds, (ii) competition for nutrients, (iii) competition for adhesion sites in the gastrointestinal tract, (iv) enhancement of theimmune response and (v) production of essential nutrients such as vitamins and fatty acids, and enzymatic contribution to digestion (Verschuere et al., 2000; Vine et al., 2006). Given this circumstance, actinomycetes should be considered as potential probiotic strains in shrimp culture. You et al. (2005) described the potential of actinomycetes against shrimp pathogenic Vibrio spp. Kumar et al. (2006) extracted the antibiotic product from marine actinomycetes and incorporated it into feed to observe the in vivo effect on white spot syndrome virus in black tiger shrimp. Das et al. (2006) reported a preliminary study on the effect of probiotic supplementation of Streptomyces on the growth and aids in preventing disease of black tiger shrimp, Penaeus monodon (Fabricius). You et al. (2007) recommended the use of actinomycetes to prevent the disease caused by Vibrio spp. Folowing this trend, Streptomyces sp. A1 isolated in the present study showed the activity against two pathogenic strains Vibrio sp. V7 and V10 through production of inhibitory compounds and siderophore. The likely mode of action against pathogenic bacteria of Streptomyces projected that it release antibiotics in a sort of biochemical warfare to eliminate the competing microorganisms from the environment. These antibiotics are small molecules and interfere with gyrase protein, which assists in DNA replication. As a result, pathogenic bacteria are not able to divide normally. However, Streptomyces protects itself from its own antibiotics by the production of efflux pumps (used against the influx of antibiotics), ribosomal protection proteins (protect ribosome and prevents interfering with 
protein synthesis), and modifying enzymes (neutralize antibiotics by the production of acetyl or phosphate groups) (Das et al., 2008). Iron is a limiting bioactive metal in seawater and essential for the growth of marine bacteria. Thus, marine bacteria have to develop some strategies to acquire iron. The major strategy is the production and utilization of siderophores. Siderophores, low molecular weight high-affinity ferric iron chelators, are synthesized and secreted by many microorganisms in response to iron deprivation. The marine actinomycetes that can produce siderophores could adapt to the iron stress conditions in marine environment, even compete for iron with the pathogens. Competition for iron is also a possible mechanism for aquaculture probiotics to control the pathogens. So the siderophore-producing Streptomyces strains could influence the growth of pathogenic Vibrio spp. by competition for iron in marine sediments. Otherwise, Streptomyces can form heatand desiccation-resistant spores, and the probiotic products would be stable in preservation. Streptomyces sp. A1 can be mass-cultured, harvested, and fortified to feed. In this case, the positive effect may be obtained (Kumar et al., 2006). Therefore, in the present study, Streptomyces sp. A1 will be promising candidates as aquaculture probiotics.

\section{ACKNOWLEDGEMENTS}

This study was funded by the Vietnam's National Foundation for Science and Technology Development (NAFOSTED).

\section{REFERENCES}

Austin, B. 1989 Novel pharmaceutical compounds from marine bacteria. J. Appl. Bacteriol., 67(5): 461-470

Barcina, I., J. Iriberri and L. Egea 1987 Enumeration isolation and some physiological properties of actinomycetes from sea water and sediment. Syst. Appl. Microbiol., 10: 85-91

Bauer, A. W., W. M. Kirby, J. C. Sherris and M. Turck 1966 Antibiotics susceptibility testing by standardized single disk method. Am. J. Clin. Pathol., 45: 493-496

Boyd, C. E. 1992 Shrimp pond bottom soil and sediment management. In: "Proceedings of the Special Session on Shrimp Farming", ed. by J. Wyban, World Aquaculture Society, Baton Rouge, Louisiana, pp. 166-181

Boyd, C. E. 1995 Bottom Soils, Sediment, and Pond Aquaculture. Chapman \& Hall, NewYork (USA) pp. 348

Cabello, F. C. 2006 Heavy use of prophylactic antibiotics in aquaculture: a growing problem for human and animal health and for the environment. Environ. Microbiol., 8(7): 1137-1144

Das, S., P. S. Lyla and S. A. Khan 2006 Application of Streptomyces as a probiotic in the laboratory culture of Penaeus monodon (Fabricius). Isr. J. Aquac. Bamidgeh., 58: 198-204

Das, S., R. L. Ward and C. Burke 2008 Prospects of using marine actinobacteria as probiotics in aquaculture. Appl. Microbiol. Biotechnol., 81(3): 419-429

Gately, R. J. 1990 Organic carbon concentrations in bottom soils of ponds: variability, changes over time, and effects of aeration. Master's thesis, Auburn Univ. Press, Alabama, pp.
30

Jayasree, L., P. Janakiram and R. Madhavi 2006 Characterization of Vibrio spp. associated with diseased shrimp from culture ponds of Andhra Pradesh (India). J. World Aquacult. Soc., 37(4): 523-532

Kesarcodi, W. A., H. Kaspar, M. J. Lategan and L. Gibson 2008 Probiotics in aquaculture: The need, principles and mechanisms of action and screening processes. Aquaculture, 274(1): $1-14$

Kumar, S. S., R. Philip and C. T. Achuthankutty 2006 Antiviral property of marine actinomycetes against white spot syndrome virus in penaeid shrimps. Curr. Sci., 91: 807-811

Molina, A. A., G. A. Garcia, G. A. Abreu, M. C. Bolan, A. Roque and G. B. Gomez 2002 Plasmid profiling and antibiotic resistance of Vibrio strains isolated from cultured penaeid shrimp. FEMS Microbiol. Lett., 213(1): 7-12

Najiah, M., S. W. Lee and W. Wendy 2008 Phenotypic and genotypic characteristics of Vibrio harveyi isolated from black tiger shrimp (Penaeus monodon). World Appl. Sci. J., 3(6): 885-902

Nakayama, T., E. Ito, N. Nomura and M. Matsumura 2006 Comparison of Vibrio harveyi strains isolated from shrimp farms and from culture collection in terms of toxicity and antibiotic resistance. FEMS Microbiol. Lett., 258(2): 194-199

Nelson, D. W. and L. E. Sommers 1982 Total carbon, organic carbon, and organic matter. In "Methods of Soil Analysis", part w, ed. by A. L. Page, American Society of Agronomy Press Inc., USA, pp. 1159

Oskay, M., A. U. Tamer and C. Azeri 2004 Antibacterial activity of some actinomycetes isolated from farming soils of Turkey. Afr. J. Biotechnol., 3(9): 441-446

Payne, M. S. 1994 Detection, Isolation, and Characterization of Siderophores. Methods Enzymol., 325: 329-344

Sambrook, J. and D. W. Russell 2001 Molecular Cloning: A Laboratory Manual. $3^{\text {rd }}$ ed. Cold Spring Harbor Laboratory Press, Cold Spring Harbor, New York (USA)

Teo, J. W., T. M. Tan and L. P. Chit 2002 Genetic determinants of tetracycline resistance in Vibrio harveyi. Antimicrob. Agents Chemother., 46(4): 1038-1045

Tom, D., B. Nico, S. Patrick, V. Willy and B. Peter 2007 Alternatives to antibiotics to control bacterial infections: luminescent vibriosis in aquaculture as an example. Trends Biotechnol., 25(10): $472-479$

Vera, P., J. I. Navas and M. C. Quintero 1992 Experimental study of virulence of three species of Vibrio bacteria in Penaeus japonicus (Bate 1881) juveniles. Aquaculture, 107(2-3): $119-123$

Verschuere, L., G. Rombaut, P. Sorgeloos and W. Verstraete 2000 Probiotic bacteria as biological control agents in aquaculture. Microbiol. Mol. Biol. R., 64(4): 655-671

Vine, N. G., W. D. Leukes and H. Kaiser 2006 Probiotics in marine larviculture. FEMS Microbiol. Rev., 30(3): 404-427

Williams, S. T., S. Lanning and E. M. H. Wellington 1984 Ecology of actinomycetes. In "The biology of actinomycetes", ed. by M. Goodfellow, M. Mordarski and S. T. Williams, Academic Press Inc., London, pp. 481-528

Yang, J., L. Chen, L. Sun, J. Yu and Q. Jin 2007 VFDB 2008 release: an enhanced web-based resource for comparative pathogenomics. Nucleic. Acids. Res., 36: 539-542

You, J., L. X. Cao, G. F. Liu, S. N. Zhou, H. M. Tan and Y. C. Lin 2005 Isolation and characterization of actinomycetes antagonistic to pathogenic Vibrio spp. from nearshore marine sediments. World. J. Microb. Biot., 21(5): 679-682

You, J., X. Xue, L. Cao, X. Lu, J. Wang, L. Zhang and S. Zhou 2007 Inhibition of Vibrio biofilm formation by a marine actinomycete strain A66. Appl. Microbiol. Biotechnol., 76(5): 11371144 